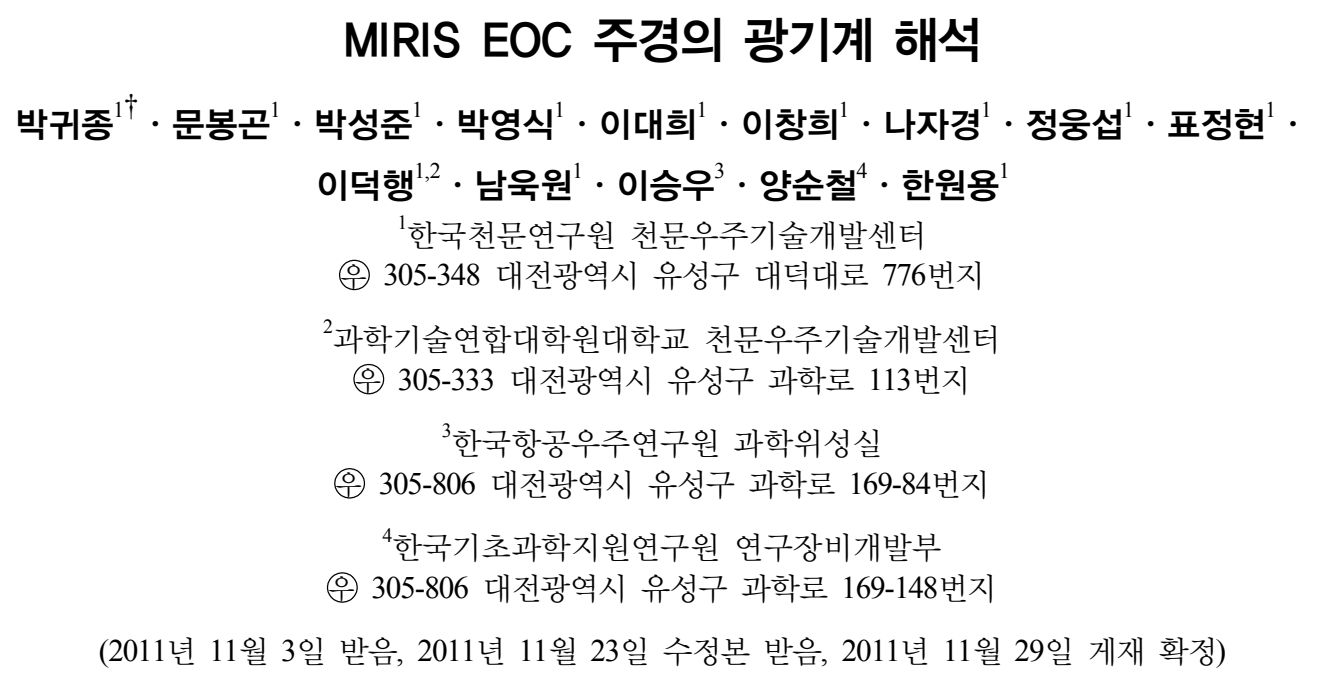

한국천문연구원이 개발한 다목적적외선영상시스템(Multi-purpose IR Imaging System, MIRIS)은 과학기술위성 3호(STSAT-3) 의 주탑재체이다. 지구관측카메라(Earth Observation Camera, EOC)는 MIRIS를 구성하는 두 개의 적외선 카메라 중에 하나로,

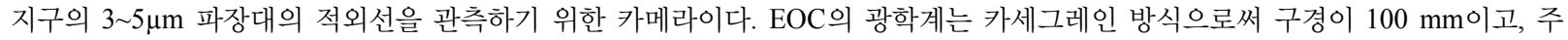
경과 부경은 모두 비구면 반사경이다. $\mathrm{EOC}$ 주경의 플렉서는 링 타입으로써 발사환경에서 주경이 겪을 수 있는 충격과 진동을 견디도록 예압을 가하며 주경을 지지한다. 이는 마치 리테이너로 렌즈를 지지하는 것과 같은 메커니즘으로 주경을 지지하기 위한 시도이다. 광기계 해석을 통해 $\mathrm{EOC}$ 주경이 효과적으로 지지되고 있음을 확인했다.

\title{
Opto-mechanical Analysis for Primary Mirror of Earth Observation Camera of the MIRIS
}

\footnotetext{
Kwijong Park ${ }^{1 \dagger}$, Bongkon Moon ${ }^{1}$, Sung-Jun Park ${ }^{1}$, Youngsik Park ${ }^{1}$, Dae-Hee Lee ${ }^{1}$, Chang Hee Ree ${ }^{1}$, Jakyoung $\mathrm{Nah}^{1}$, Woog-Seob Jeong ${ }^{1}$, Jeonghyun Pyo ${ }^{1}$, Duk-Hang Lee ${ }^{1,2}$, Uk-Won Nam ${ }^{1}$, Seung-Wu Rhee ${ }^{3}$, Sun-Choel Yang ${ }^{4}$, and Wonyong Han ${ }^{1}$ ${ }^{1}$ Astronomy and Space Technology R\&D Center, Korea Astronomy and Space Science Institute, 776 Daedeok-daero, Yuseong-gu, Daejeon 305-348, Korea

${ }^{2}$ Astronomy and Space Technology $R \& D$ Center, University of Science and Technology, 113 Gwahangno, Yuseong-gu, Daejeon 305-333, Korea

${ }^{3}$ Division of Science Satellite, Korea Aerospace Research Institute, 169-84 Gwahangno, Yuseong-gu, Daejeon 305-806, Korea ${ }^{4}$ Division of Instrument Development, Korea Basic Science Institute, 169-148 Gwahangno, Yuseong-gu, Daejeon 305-806, Korea

(Received November 3, 2011; Revised manuscript November 23, 2011; Accepted November 29, 2011)

MIRIS(Multi-purpose Infra-Red Imaging System) is the main payload of the STSAT-3(Korea Science and Technology Satellite3), which is being developed by KASI(Korea Astronomy \& Space Institute). EOC(Earth Observation Camera), which is one of two infrared cameras in MIRIS, is the camera for observing infrared rays from the Earth in the range of $3 \sim 5 \mu \mathrm{m}$. The optical system of the EOC is a Cassegrain prescription with aspheric primary and secondary mirrors, and its aperture is $100 \mathrm{~mm}$. A ring type flexure supports the EOC primary mirror with pre-loading in order to withstand expected load due to the shock and vibration from the launcher. Here we attempt to use the same mechanism by which a retainer supports the lens. Through opto-mechanical analysis it was confirmed that the EOC primary mirror is effectively supported.
}

Keywords: MIRIS, Mirror, Opto-mechanics, Zernike polynomial, Lens mount OCIS codes: (200.4880) Optomechanics; (230.4040) Mirrors; (350.6090) Space optics

${ }^{\dagger}$ E-mail: pkj@kasi.re.kr

Color versions of one or more of the figures in this paper are available online. 


\section{I. 서 론}

과학기술위성 3호의 주탑채체인 다목적적외선영상시스템 (Multi-purpose IR Imaging System, MIRIS)은 두 개의 적외 선 카메라로 구성된다. 하나는 우주를 관측하기 위한 우주관 측카메라(Space Observation Camera, SOC)이고, 다른 하나는 지구를 관측하기 위한 지구관측카메라(Earth Observation Camera, $\mathrm{EOC})$ 이다 ${ }^{[1-3]}$. $\mathrm{EOC}$ 는 구경이 $100 \mathrm{~mm}$ 로써 지구의 $3 \sim 5 \mu \mathrm{m}$ 파장대의 적외선을 관측하기 위한 카메라이다. 또 한, 국산 적외선 센서의 우주 인증이라는 목적과 함께 유사 시 한반도를 적외선으로 감시하기 위해 개발되었다 ${ }^{[4]} . \mathrm{EOC}$ 의 질량은 약 $10 \mathrm{~kg}$ 이고, 전체형상은 그림 $1(\mathrm{a})$ 에 나타내었 다 ${ }^{[5]}$. 주요 광학계는 상온에서 운영되고 검출기와 듀어는 소 형 냉동기에 의해 $80 \mathrm{~K}$ 로 냉각된다. $\mathrm{EOC}$ 의 광학계는 카세그

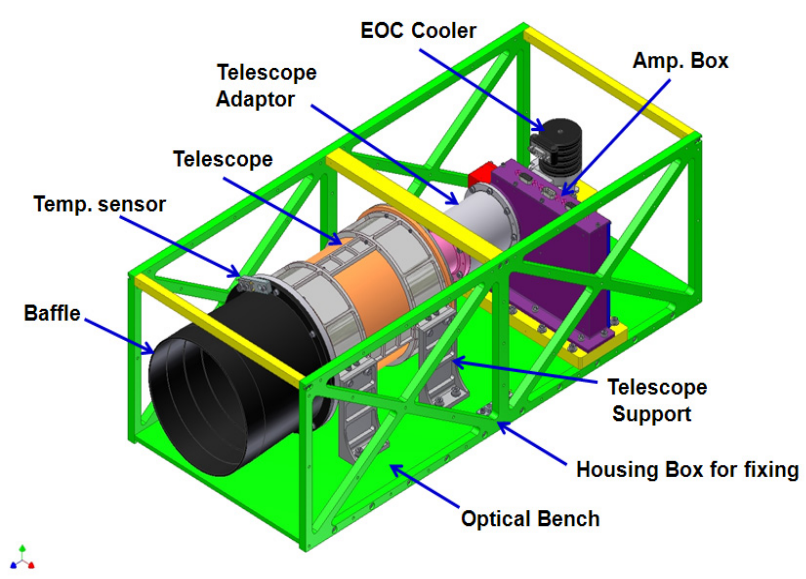

(a)

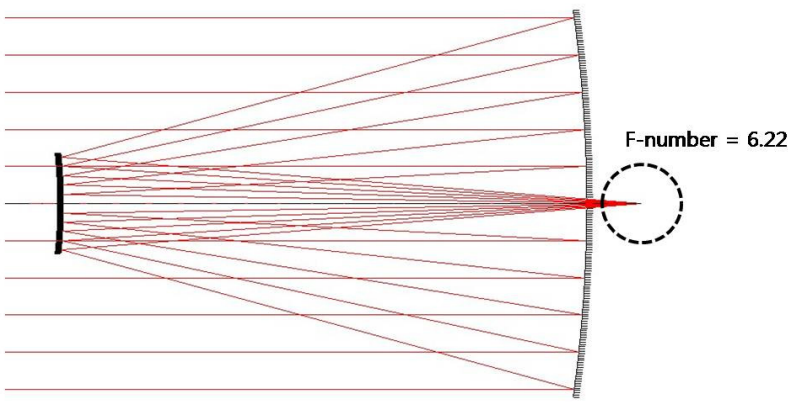

(b)

FIG. 1. (a) Solid model of EOC, (b) Optical system: Cassegrain prescription.
레인 방식으로써 제로더 재질의 주경과 부경은 모두 비구면 반사경이다. 그림 $1(\mathrm{~b})$ 에 나타낸 것과 같이, 주경과 부경에 의한 F-수는 6.22 이다.

광기계 해석을 통해, $\mathrm{EOC}$ 주경을 마치 렌즈처럼 지지 ${ }^{[6]}$ 했 을 때, 주경과 지지구조물의 고유진동수와 주경의 광학적 성 능을 분석하였다. $\mathrm{EOC}$ 주경의 광학성능 요구조건은 $\mathrm{WFE}$ $\mathrm{P}-\mathrm{V}$ (Peak to Valley) $<\lambda / 8$ 이다. 사용된 소프트웨어로는 $\mathrm{NX}$ I-deas와 SolidWorks, Matlab이다.

\section{EOC 주경 모듈}

$\mathrm{EOC}$ 주경의 광학 데이터를 표 1에 나타내었다. 코닉상수, $\mathrm{K}$ 는 -0.863782 로써 주경의 표면은 타원면을 형성한다.

$\mathrm{EOC}$ 주경 모듈을 그림 2에 나타냈다. $\mathrm{EOC}$ 의 배럴 내부를 보면, 셀 위에 주경이 접촉상태로 놓이고, 링 타입의 플렉서 와 합성고무(elastomer)인 Viton 오링이 주경과 조립된다. 주경 과 오링을 제외하고 나머지 부품의 재질은 모두 알루미늄합금 (A16061-T6)이다. 표 2에 재료의 물성치를 나타냈다. 주경의 최대두께는 $13.5 \mathrm{~mm}$ 로써 총 무게는 $0.271 \mathrm{~kg}$ 이다. 광축방향 을 축방향으로 정의하고, 광축방향과 수직인 방향을 횡방향 으로 정의했을 때, 주경의 축방향의 자중은 플렉서와 셀에 의해 지지가 되고, 횡방향의 자중은 3 개의 오링에 의해 지지

TABLE 1. Optical data of EOC primary mirror

\begin{tabular}{l|l}
\hline \hline Diameter & $110 \mathrm{~mm}$ \\
\hline Clear Aperture & $100 \mathrm{~mm}$ \\
\hline Radius of Curvature, ROC & $374.728 \mathrm{~mm}$ \\
\hline Conic Constant, K & -0.863782 \\
\hline
\end{tabular}

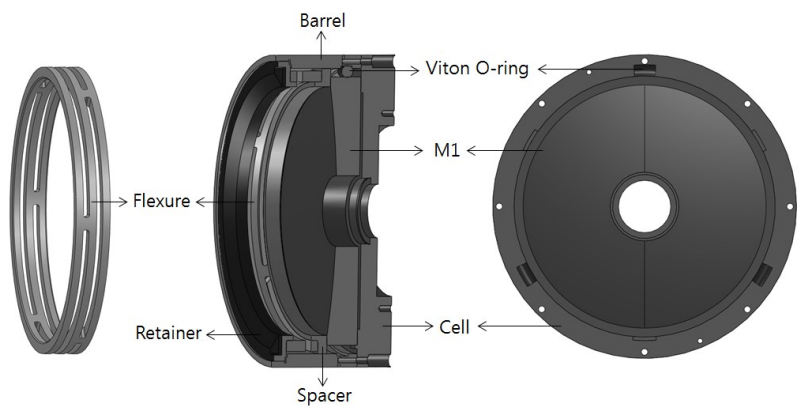

FIG. 2. Module parts of EOC primary mirror: mirror, cell, flexure, o-ring, barrel, spacer, retainer.

TABLE 2. Material properties

\begin{tabular}{c|c|c|c|c|c}
\hline \hline Material & $\mathrm{E}(\mathrm{Pa})$ & $v$ & $\rho\left(\mathrm{kg} / \mathrm{m}^{3}\right)$ & $\mathrm{CTE}\left(10^{-6} / \mathrm{K}\right)$ & Note \\
\hline Al6061-T6 & $6.9 \times 10^{10}$ & 0.33 & 2700 & 24.0 & Yield Strength: 275MPa \\
\hline Zerodur & $9.2 \times 10^{10}$ & 0.24 & 2530 & 0.05 & Tensile Strength: $57 \mathrm{MPa}$ \\
\hline Viton O-ring & $8.04 \times 10^{5}$ & 0.49 & 1850 & 2.6 & \\
\hline
\end{tabular}


가 된다. 플렉서는 주경이 위성의 발사환경에서 겪을 수 있 는 충격과 진동을 견딜 수 있도록 주경의 앞면의 외곽면에 접촉하여 예압(pre-load)을 가하며 조립이 된다. 플렉서가 주 경 앞면의 외곽면에 가하는 총 힘은 $170.3 \mathrm{~N}$ 로써 중력가속 도가 약 $64 \mathrm{G}$ 에 해당한다. 플렉서가 주경을 누르는 외각면의 크기는 내경이 $102.4 \mathrm{~mm}$, 폭이 $3.8 \mathrm{~mm}$ 이고, 주경이 셀에 지 지되는 외각면의 크기는 내경이 $97 \mathrm{~mm}$, 폭이 $6.5 \mathrm{~mm}$ 이다. 리테이너가 렌즈를 지지하는 것과 같은 메커니즘으로 플렉 서가 주경을 접촉으로 지지하기 때문에 열변형이 크게 발생 하지 않을 것으로 기대된다. 오링은 파이프 형상으로 직경이 $5 \mathrm{~mm}$ 로써 3 개의 오링이 주경과 배럴 사이에 끼워져 주경의 외주연에 압력을 가하게 되지만, 해석의 편의를 위해서 오링 의 단면을 정사각형 $(5 \mathrm{~mm} \times 5 \mathrm{~mm})$ 으로 간주했다. 1 개의 오 링이 접촉하는 면적은 $45.5 \mathrm{~mm}^{2}$ (가로 $9.1 \mathrm{~mm} \times$ 세로 $5 \mathrm{~mm}$ ) 이고, 조립 시에 눌리는 변위는 $0.62 \mathrm{~mm}$ 로써 공칭변형율이 0.124 에 해당한다. 주경 외주연 전체를 누를 수 있는 길이의 오링을 압축시험으로 측정한 스프링상수는 $2.78 \times 10^{5}$ 로 얻 어졌다. 이것을 배럴과 주경 사이에 끼웠다고 가정했을 때, $0.62 \mathrm{~mm}$ 가 눌리면 $172.36 \mathrm{~N}$ 의 힘이 발생한다고 볼 수 있다. 이 힘을 오링의 전체 접촉면적으로 나누면 오링이 주경 외주 연을 누르는 압력은 $172.36 \mathrm{~N} \div(\pi \times$ 주경 직경 $110 \mathrm{~mm} \times$ 접촉 높이 $5 \mathrm{~mm})=0.0998 \mathrm{MPa}$ 로 계산된다.

\section{III. 광기계 해석}

\section{1. 고유진동수}

유한요소해석을 수행하기 위해, 사면체 10 절점 요소를 사 용하여 총 49,553 개의 요소와, 70,737 개의 절점으로 주경의 유한요소모델을 생성했다. 주경의 단면과 유한요소모델을 그 림 3에 나타냈다. 유한요소모델의 질량은 $0.271 \mathrm{~kg}$ 이고, 무게 중심은 밑면에서부터 광축방향으로 $6.1 \mathrm{~mm}$ 떨어져있다.

플렉서와 오링은 주경에 접촉하여 조립되므로 횡방향 운동 과 축방향 운동이 비연계되게 된다. 플렉서의 강성을 파악하 기 위해 플렉서가 주경과 조립된 경우에 대해서 고유진동수 해석을 수행했다. 주경과 접촉하지 않는 플렉서의 한쪽면의 축방향 변위를 고정하고, 주경 외주연의 원주방향 변위를 고 정한 경계조건에서 플렉서는 주경과 함께 $146 \mathrm{~Hz}$ 의 강성을 가진다. 그림 4(a)에 플렉서와 주경의 $1^{\text {st }}$ 모드 형상을 나타내 었다. 오링의 스프링상수는 $2.78 \times 10^{5}$ 이고, 고유진동수는 $(1 / 2 \pi) \times(\text { 스프링상수/질량 })^{1 / 2}$ 이므로 주경과 함께 $161.3 \mathrm{~Hz}$ 에 서 $1^{\text {st }}$ 모드가 발생하는 것으로 예상할 수 있다. 주경의 고유 한 강성을 파악하기 위해서 자유 경계조건(free-free boundary condition)에서 고유진동수 해석을 수행했다 ${ }^{[7,8]}$. 주경의 $1^{\text {st }}$ 모 드는 그림 4(b)와 같이 비점수차 형상으로 $5170 \mathrm{~Hz}$ 에서 발생

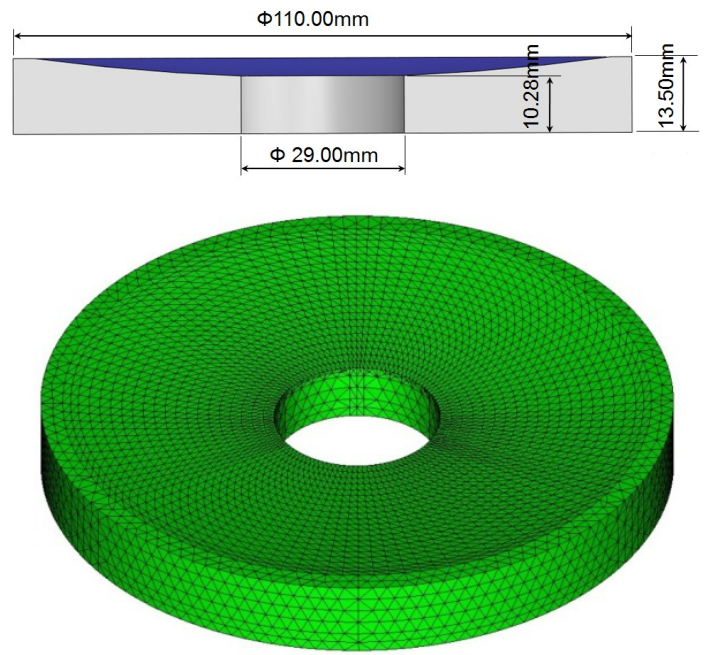

FIG. 3. Section area and finite element model of EOC primary mirror.

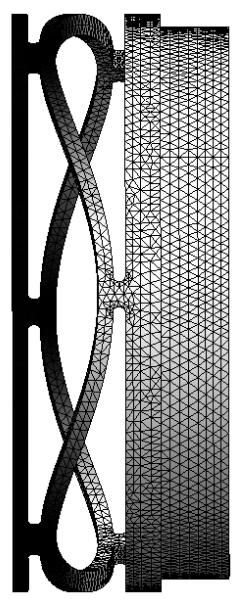

(a)

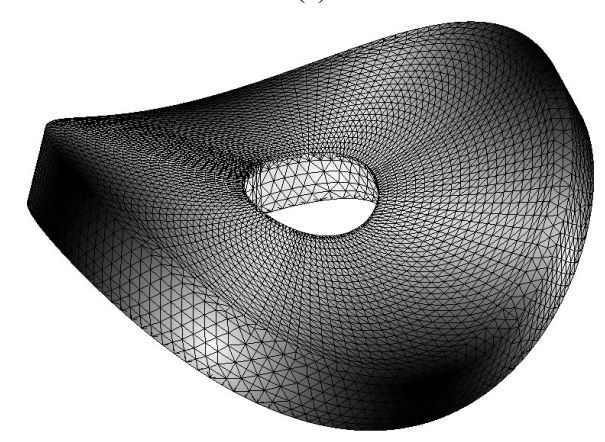

(b)

FIG 4. $1^{\text {st }}$ mode configuration: (a) Flexure with EOC primary mirror(146 Hz), (b) EOC primary mirror $(5170 \mathrm{~Hz})$.

한다. 이는 플렉서와 오링에 비해 주경의 강성이 상대적으로 큰 값으로써 플렉서와 오링이 주경을 유연하게 지지할 수 있 음을 의미한다. 


\section{2. 플렉서와 오링에 의한 예압}

$\mathrm{EOC}$ 주경이 위성의 발사환경에서 겪을 수 있는 하중을 견 디기 위해 플렉서와 오링은 주경에 예압을 가하며 조립이 된 다. 먼저 플렉서의 예압이 주경의 광학적 성능에 미치는 영 향을 분석했다. 주경과 셀이 접촉하는 영역의 축방향 변위를 고정하고, 주경 외주연의 원주방향 변위를 고정한 경계조건 에서 플렉서와 주경이 접촉하는 앞면의 외곽면에 $170.3 \mathrm{~N}$ 의 힘을 가했다. 주경의 응력분포와 변형형상을 그림 $5(\mathrm{a})$ 와 같 이 나타내었다. 총 변위는 $30 \mu \mathrm{m}$ 로 계산되었으며, 최대 응력 은 $0.165 \mathrm{MPa}$ 로써 제로더의 인장강도 $57 \mathrm{MPa}$ 에 비해 안전함 을 확인했다. 주경의 표면 변형량으로부터 Zernike 다항식 피팅 ${ }^{[9]}$ 을 통해 광학수차를 제거하면 광학적 표면 변형형상 (optical surface deformation map)을 구할 수 있다. 그림 5(b) 는 피스톤, 팁, 틸트 수차를 보정한 후의 표면 변형형상이다. 플렉서의 누르는 힘에 의해 주경 표면의 P-V는 $39.9 \mathrm{~nm}$ 이 고, RMS(Root Mean Square)는 $11.0 \mathrm{~nm}$ 에 해당하는 변형이 발생하였다. 반사경의 경우 표면 변형량에 의해 입사광의 오 차만큼 반사광에서도 오차를 가지고 다시 반사되기 때문에 파면오차(Wavefront Error, WFE)는 표면 변형량의 2 배가 된

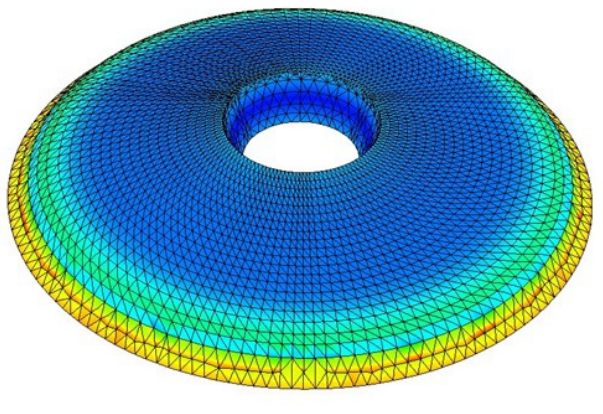

(a)

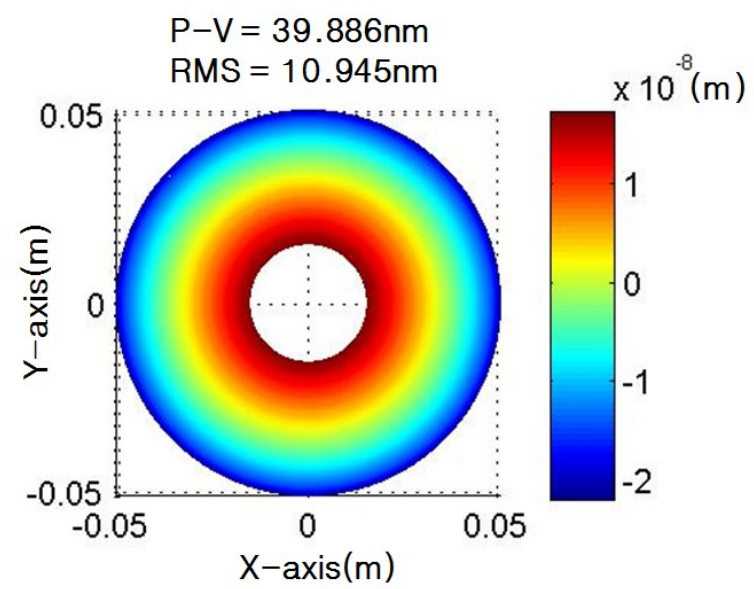

(b)

FIG. 5. Analysis results for flexure pre-load: (a) Stress distribution and deformed configuration, (b) Optical surface deformation map.
다. 그러므로, 플렉서에 의해 발생하는 WFE의 P-V는 79.8 $\mathrm{nm}, \mathrm{RMS}$ 는 $21.9 \mathrm{~nm}$ 가 되고, 이는 WFE $\mathrm{P}-\mathrm{V}$ 가 $\lambda / 37.5 \sim \lambda$ $/ 62.5$ 에 해당하는 것으로 요구조건 $\lambda / 8$ 를 만족한다. 주경의 광학적 표면 변형형상을 보면, 디포커스 수차가 지배적이다. 3 개의 오링이 주경의 외주연을 누르는 예압에 의한 주경의 영향을 분석하였다. 앞의 해석과 동일한 경계조건에서 하중 으로 주경의 외주연에 오링이 접촉하는 영역에 $0.0998 \mathrm{MPa}$ 의 압력을 가했다. 주경에 발생한 최대 응력은 $0.09 \mathrm{MPa}$ 로 써 플렉서에 의한 영향보다 미비하다. 그림 6에 오링에 의한 응력분포와 광학적 표면 변형형상을 나타내었다. WFE P-V 는 $3.1 \mathrm{~nm}, \mathrm{RMS}$ 는 $0.53 \mathrm{~nm}$ 로써 오링에 의한 압력은 주경의 변형에 거의 영향을 주지 않는다.

조립오차에 의한 주경의 성능을 예측하기 위해서 플렉서와 오링이 주경을 누르는 예압에 대한 공차분석을 수행했다. 그 림 7은 주경을 누르는 예압을 1 배씩 증가시킬 때 주경의 WFE P-V와 RMS의 증가량을 나타내는 그래프이다. 플렉서 와 오링이 누르는 예압에 대해 주경의 WFE RMS와 P-V가 선형적으로 증가하고 있다. 플렉서가 주경을 누르는 예압을 10 배 증가하면 주경의 $\mathrm{P}-\mathrm{V}$ 가 약 $40 \mathrm{~nm}$ 에서 약 $400 \mathrm{~nm}$ 로 10

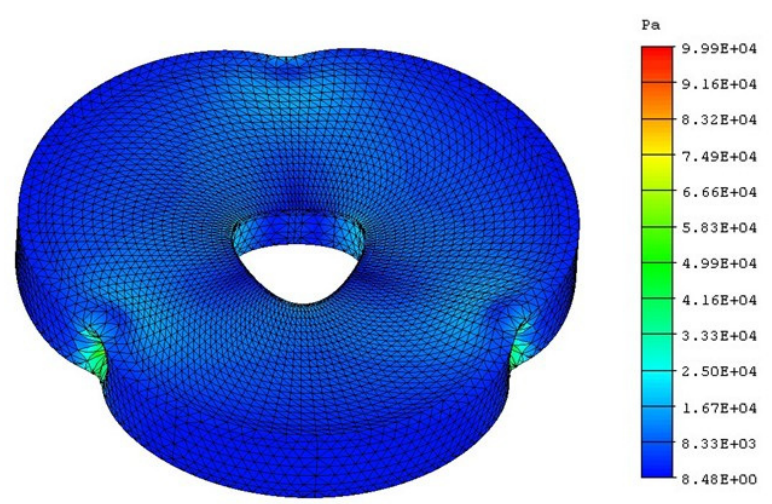

(a)

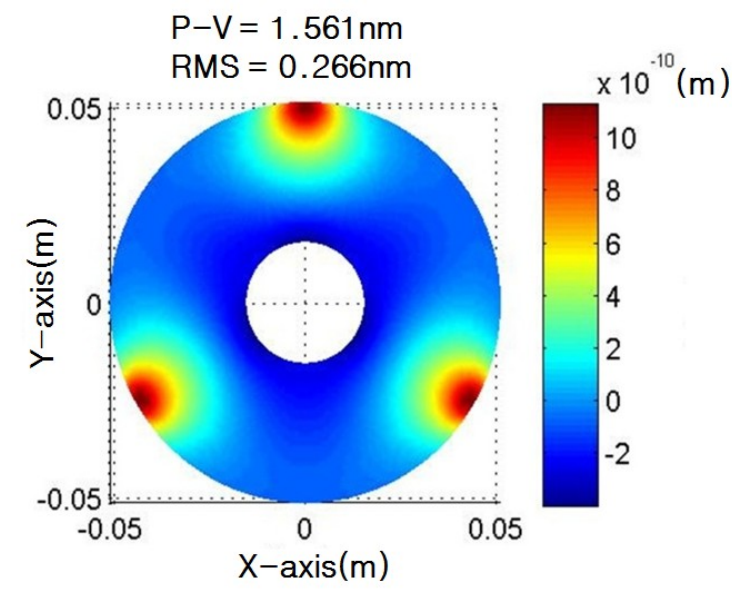

(b)

FIG. 6. Analysis results for o-ring pre-load: (a) Stress distribution and deformed configuration, (b) Optical surface deformation map. 


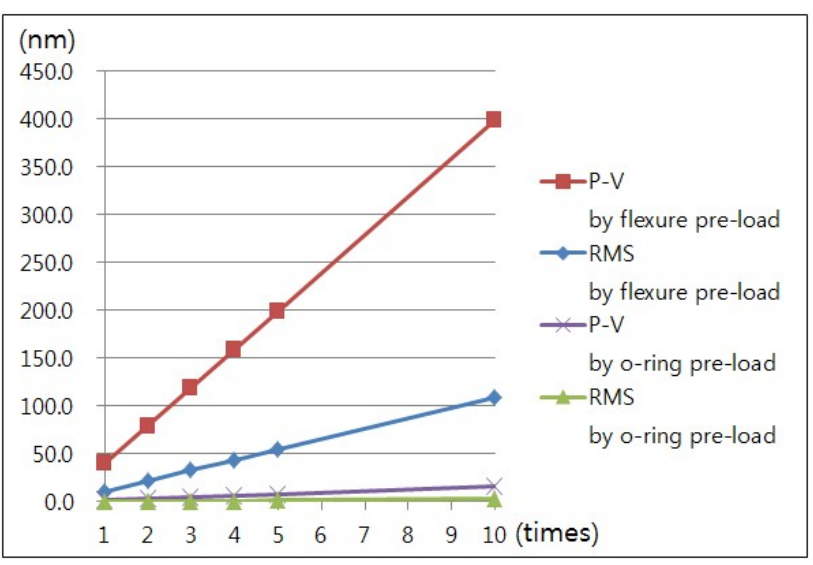

FIG. 7. WFE change rate for increase of flexure and o-ring pre-load.

배 증가한다. 본 해석을 비선형 대변형해석으로 간주하여 예 압을 단계적으로 증가시키며 계산해 보았지만, 동일한 선형 그래프를 얻었다. 그 이유는 플렉서의 예압을 10 배 증가시켜 도 주경의 표면 변형이 미소하여 거동이 응력-변형율 곡선의 선형 구간에 존재하기 때문이다. 관측 적외선 파장이 $3 \mu \mathrm{m}$ $5 \mu \mathrm{m}$ 인 것을 고려했을 때, 예압을 9.4배 15.6배를 가해도 주경의 예상 변형량은 요구조건 WFE P-V $\lambda / 8$ 를 만족한다. 이것은 발사환경에서 발생하는 충격과 진동을 견디기 위해 플렉서의 예압을 강하게 가할 수 있는 여유가 있음을 의미한 다. 플렉서의 고유진동수 $146 \mathrm{~Hz}$ 로부터 스프링상수를 구하 면 $227.8 \mathrm{kN} / \mathrm{m}$ 이 되고, 허용 예압을 이 스프링 상수로 나누 면, WFE 요구조건을 만족하는 플렉서의 조립공차는 축방향 으로 $7.0 \mu \mathrm{m} \sim 11.7 \mu \mathrm{m}$ 가 된다. 플렉서의 예압에 비해 오링은 주경의 성능에 거의 영향을 주지 않음을 그림 7 의 그래프에 서 확인하게 된다.

\section{3. 중력}

횡방향으로 중력이 작용하고 플렉서와 오링에 의한 예압이 동시에 가해지고 있는 상황에서의 $\mathrm{EOC}$ 주경의 광학적 성능 을 평가했다. 앞의 플렉서의 예압을 주경에 가하는 해석과 동일한 경계조건에서 플렉서와 오링의 예압에 횡방향 중력 이 추가되었다. 그림 8(a)에 광학적 표면 변형형상을 나타내 었다. WFE가 P-V는 $77.4 \mathrm{~nm}, \mathrm{RMS}$ 는 $20.9 \mathrm{~nm}$ 로 계산되었는 데 표면 변형량이 플렉서의 예압만 작용할 때 보다 더 작게 나왔다. 그 이유는 플렉서에 의한 예압에 의한 축방향의 변 형율을 오링에 의한 압력이 푸아송비 만큼 줄였기 때문이다. 피스톤, 팁, 틸트 수차를 보정한 후의 결과인 그림 8(a)에서 디포커스 수차를 보정하면 그림 8(b)와 같이 WFE RMS는 $1.8 \mathrm{~nm}$ 가 되고, 디포커스 수차에 의해 보이지 않았던 오링에 의한 변형 형상을 확인하게 된다.



(a)

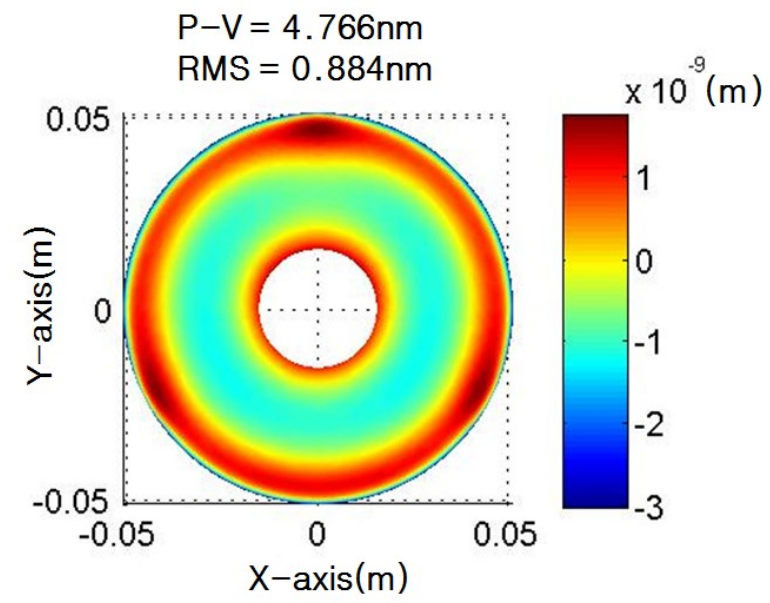

(b)

FIG. 8. (a) Optical surface deformation map, (b) Optical surface deformation map with defocus correction.

축방향으로 중력이 작용할 경우에도 주경의 광학적 성능을 분석하면 횡방향으로 중력이 작용할 경우와 거의 동일한 변 형형상을 얻게 된다. 이는 주경의 직경과 자중이 작아서 플 렉서의 예압이 주경의 표면 변형에 지배적인 인자이기 때문 이다. WFE P-V는 $70.0 \mathrm{~nm}, \mathrm{RMS}$ 는 $18.8 \mathrm{~nm}$ 로 계산되었는 데, 횡방향으로 중력이 작용하는 경우보다 변형이 작게 발생 하는 것으로 나타났다.

\section{4. 온도 변화}

온도 변화에 대한 $\mathrm{EOC}$ 주경의 변형의 경향성을 파악하기 위해서 주경이 배럴 안에서 플렉서와 셀에 접촉(contact)되어 있을 때, $\Delta \mathrm{T}= \pm 5^{\circ} \mathrm{C}$ 에 의한 주경의 광학적 성능을 분석했다. 오링이 주경에 가하는 압력은 주경의 성능에 크게 영향을 주 지 않으므로 오링은 제외했다. $\Delta \mathrm{T}=-5^{\circ} \mathrm{C}$ 인 경우의 해석을 수행하기 위해 경계조건으로 배럴의 외주연 중간 지점의 축 방향 변위와 원주방향 변위를 고정하고, 플렉서와 주경, 주 
경과 셀은 접촉으로 설정했다. 해석에서 오링은 제외했으므 로, 주경의 횡방향 이동과 축방향 회전에 대한 자유도를 구 속하기 위해 주경 외주연의 원주방향 변위를 추가적으로 고 정했다. 각 절점에 $293 \mathrm{~K}$ 의 온도를 가하고 기준온도는 $298 \mathrm{~K}$ 로 설정했다. 그림 $9(\mathrm{a})$ 는 $\Delta \mathrm{T}=-5^{\circ} \mathrm{C}$ 일 때 열탄성 해석 후에 주경 모듈의 응력분포와 변형형상의 단면을 보여준다. 주경 모듈의 열팽창에 의해 그림 $9(\mathrm{~b})$ 와 같이 주경에는 $12.2 \mathrm{KPa}$ 의 미비한 응력이 발생한다. 주경의 표면 변형량을 분석하면, 단지 피스톤 수차만 $-2.16 \mu \mathrm{m}$ 로 발생한 것을 그림 9(c)에 나 타냈다. 피스톤 수차를 제거하면 광학적 표면 변형량은 0 $\mathrm{nm}$ 가 되는데, 이것은 $\Delta \mathrm{T}=-5^{\circ} \mathrm{C}$ 에 의해 주경의 광학적 성능 이 영향을 받지 않음을 의미한다. $\Delta \mathrm{T}=+5^{\circ} \mathrm{C}$ 인 경우에 대해 서도 열탄성 해석을 수행하면 앞의 해석과 동일하게 $0 \mathrm{~nm}$ 가 되는데, 그 이유는 온도가 상승할 때 배럴이 팽창하여 플렉 서와 셀의 간격이 커져 주경과 접촉하지 않기 때문이다. 그 러므로, 온도하락보다 온도상승이 주경에는 더 유리한 조건 이라고 볼 수 있다. 열탄성 해석에서 플렉서의 예압을 생략 했지만, 실제로는 이 예압이 가해지고 있기 때문에 플렉서와 셀이 온도변화에 의해 주경과 접촉에서 분리되는 현상은 발
생하지 않을 것이다.

앞의 온도변화 $\pm 5^{\circ} \mathrm{C}$ 에 대한 결과를 바탕으로, 우주환경에 서의 $\mathrm{EOC}$ 주경의 광학적 성능을 예측해 보았다. 온도제어가 되지 않을 경우에, 우주환경에서의 $\mathrm{EOC}$ 가 받을 수 있는 온 도변화 범위는 $-18{ }^{\circ} \mathrm{C} \sim+26^{\circ} \mathrm{C}$ 이다. $+26^{\circ} \mathrm{C}$ 온도변화에 대해 서는 배럴의 팽창에 의해 주경의 광학적 표면 변형량은 0 $\mathrm{nm}$ 가 될 것이다. $-18^{\circ} \mathrm{C}$ 에서는 배럴의 수축에 의해 플렉서가 주경에 힘을 가하겠지만, 그 영향은 미비할 것으로 기대된다.

배럴 안에서 $\mathrm{EOC}$ 주경이 플렉서와 셀에 결합(bonding)이 되었을 경우에 온도 변화, $\Delta \mathrm{T}=+5^{\circ} \mathrm{C}$ 에 의한 광학적 성능도 분석했다. 경계조건으로 배럴의 외주연 중간 지점의 축방향 변위와 원주방향 변위를 고정했다. 유한요소모델에서 플렉 서, 주경, 셀의 요소가 모두 붙어 있으므로, 주경의 원주방향 변위를 따로 구속할 필요는 없다. 각 절점에 $303 \mathrm{~K}$ 의 온도를 가하고 기준온도는 $298 \mathrm{~K}$ 로 설정했다. $\Delta \mathrm{T}=+5^{\circ} \mathrm{C}$ 일 때 열탄 성 해석 후에 주경의 응력분포와 변형형상의 단면을 그림 10(a)에 나타냈다. 플렉서와 셀, 주경의 열팽창계수의 차이로 인해 최대응력이 주경에서 $16.5 \mathrm{MPa}$ 로써 접촉 경우에 비해 크게 상승한다. 또한, 주경이 심하게 변형된 것을 그림 $10(\mathrm{~b})$

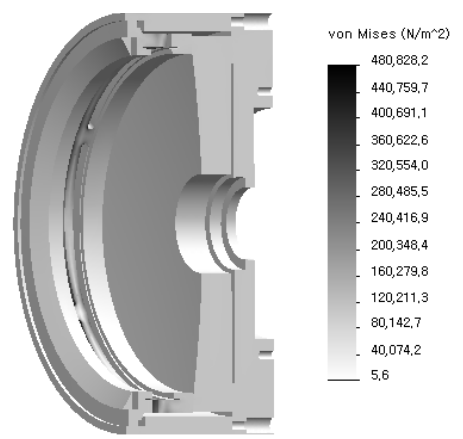

(a)



(b)

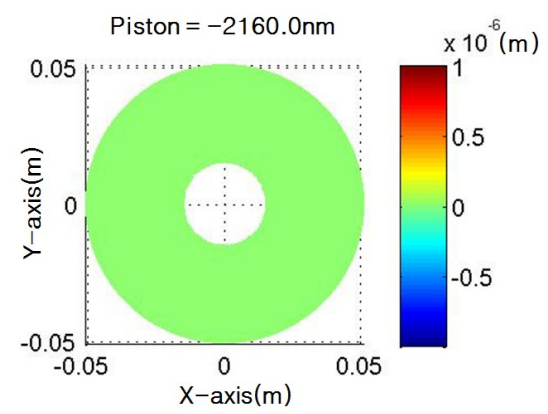

(c)

FIG. 9. Analysis result for $\Delta \mathrm{T}=-5^{\circ} \mathrm{C}$ with contact condition: (a) Stress distribution and deformed configuration of EOC module section, (b) Stress distribution and deformed configuration of EOC primary mirror, (c) Piston aberration.

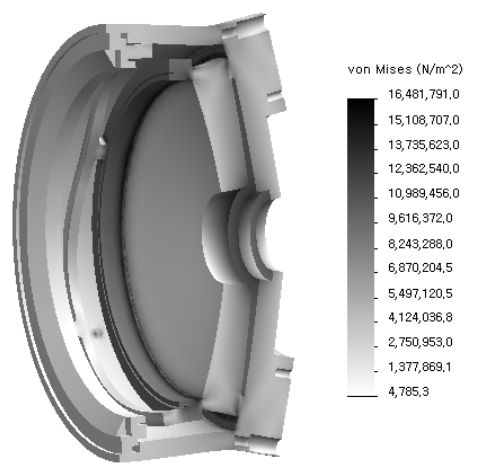

(a)

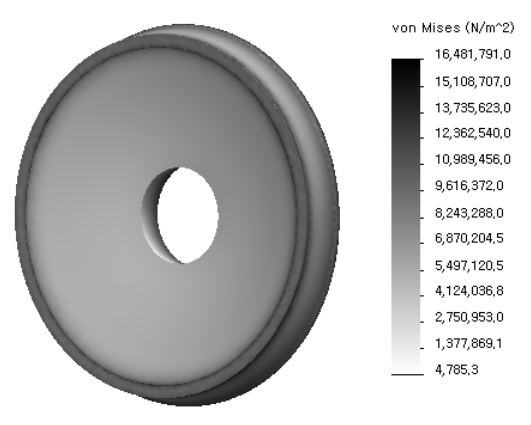

(b)

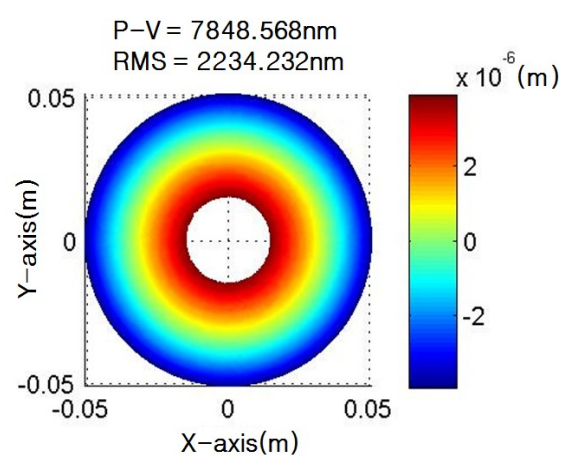

(c)

FIG. 10. Analysis result for $\Delta \mathrm{T}=+5^{\circ} \mathrm{C}$ with boding condition: (a) Stress distribution and deformed configuration for EOC module section, (b) Stress distribution and deformed configuration of EOC primary mirror, (c) Optical surface deformation map. 
TABLE 3. Result value for each condition

\begin{tabular}{|c|c|c|c|c|c|}
\hline \multicolumn{2}{|c|}{ Condition Result } & $\begin{array}{l}\text { Max. Stress } \\
(\mathrm{MPa})\end{array}$ & $\begin{array}{c}\text { WFE P-V } \\
(\mathrm{nm})\end{array}$ & $\begin{array}{l}\text { WFE RMS } \\
(\mathrm{nm})\end{array}$ & Note \\
\hline \multirow{2}{*}{ Pre-load } & Flexure & 0.165 & 79.8 & 21.9 & \\
\hline & O-ring & 0.09 & 3.1 & 0.53 & \\
\hline \multirow{2}{*}{ Gravity } & $\begin{array}{l}\text { Lateral gravity } \\
+ \text { Pre-load }\end{array}$ & 0.317 & 77.4 & 20.9 & \\
\hline & $\begin{array}{l}\text { Axial gravity } \\
+ \text { Pre-load }\end{array}$ & 0.162 & 70.0 & 18.8 & \\
\hline \multirow{2}{*}{$\begin{array}{l}\text { Temperature } \\
\text { Change }\end{array}$} & $\Delta \mathrm{T}=-5^{\circ} \mathrm{C}$, Contact & 0.012 & 0 & 0 & \\
\hline & $\Delta \mathrm{T}=+5^{\circ} \mathrm{C}$, Bonding & 17.0 & 15697.1 & 4468.5 & $>\lambda / 8$ \\
\hline
\end{tabular}

에서 확인하게 되고, 광학적 표면 변형형상을 그림 $10(\mathrm{c})$ 와 같이 구하면 주경의 WFE P-V는 $15.7 \mu \mathrm{m}, \mathrm{RMS}$ 는 $4.5 \mu \mathrm{m}$ 로 요구조건을 크게 초과한다. 하중조건과 온도조건, 경계조건 에 따른 앞의 해석결과들을 표 3과 같이 모두 비교하면, 플 렉서와 셀을 주경과 결합으로 조립했을 때의 심각성을 여실 히 보여준다.

\section{IV. 결 론}

$\mathrm{EOC}$ 주경과 지지구조물의 고유진동수와 주경의 광학적 성능을 살펴 보았다. 광기계 해석을 통해 주경을 렌즈와 같 은 메커니즘으로 지지한 시도가 아래와 같은 이유로 효과적 임을 확인했다. 첫째, 링 타입의 플렉서와 오링, 주경의 고유 진동수를 비교하여 플렉서와 오링이 주경을 유연하게 지지 하고 있음을 확인했다. 둘째, 주경의 광학적 성능에 지배적 인 영향을 미치는 것은 플렉서의 예압이고, 예압을 증가할 때 변형량이 선형적으로 증가했다. $3 \mu \mathrm{m} \sim 5 \mu \mathrm{m}$ 적외선을 관측하는 $\mathrm{EOC}$ 카메라의 경우에 9.4배 15.6배의 예압을 더 가해도 WFE 요구조건 범위 내에 있었다. 셋째, 주경이 플렉 서와 셀에 접촉으로 조립되기 때문에 $\pm 5^{\circ} \mathrm{C}$ 온도변화에 대해 주경에 변형이 발생하지 않았다.

$\mathrm{EOC}$ 주경의 표면 변형량이 작기 때문에, $\mathrm{EOC}$ 주경과 같 이 링 타입의 플렉서로 지지하는 방법은 반사경의 직경이 작 은 경우에 가시광선 관측용 카메라에도 적용이 가능할 것으 로 기대된다.

\section{References}

1. W. Han, D.-H. Lee, Y. Park, W. S. Jeong, and C. H. Ree, "System design of compact IR space imasing system MIRIS," Proc. SPIE 7731, 77311W (2010).

2. B. Moon, W. S. Jeong, S. M. Cha, Y. Park, and C. H. Ree, "Development of mechanical structure for the compact space IR camera MIRIS," Proc. SPIE 7731, 77311Y (2010).

3. C. H. Ree, S. J. Park, B. Moon, S. M. Cha, and Y. Park, "Optical design and performance of MIRIS near-infrared camera," Proc. SPIE 7731, 77311X (2010).

4. KARI, STSAT-3 CDR Report (Korea Aerospace Research Institute, Daejeon, 2009).

5. S. J. Park, D.-H. Lee, Y. Park, C. H. Ree, and B. Moon, "Development of STSAT-3 main payload MIRIS earth observation camera," Proc. ISRS, 1400 (2010).

6. P. R. Yoder, Opto-mechanical System Design (Marcel Dekker, New York, USA, 1993), pp. 155-462.

7. S. Heo and M. K. Kwak, "Free vibration analysis of an annular plate by the independent coordinate coupling method," J. KSNVE 18, 564-571 (2008).

8. M. K. Cho, M. Liang, and D. R. Neill, "Performance prediction of the LSST secondary mirror," Proc. SPIE 7424, 742407 (2009).

9. R. J. Noll, "Zernike polynomials and atmospheric turbulence," J. Opt. Soc. Am. 66, 207-211 (1976). 